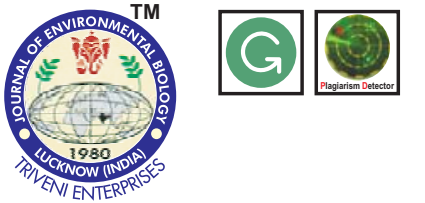

DOI : http://doi.org/10.22438/jeb/38/4/MRN-618

\title{
Screening and identification of oleaginous moulds for lipid production
}

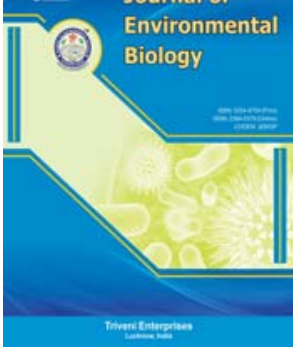

\section{Authors Info}

\section{B. Sheerin Banu*, Ramprasad Kuncham ${ }^{2}$, M.A. Azeem ${ }^{3}$ and M.R. Bharath ${ }^{1}$}

${ }^{1}$ Research and Development Centre, Bharathiar University, Coimbatore-641 046, India

${ }^{2}$ Eurofins Genomics India Pvt. Ltd., Whitefield, Bengaluru-560 048, India

${ }^{3}$ Department of Pharmacognosy, Al-Ameen College of Pharmacy, Bangalore-560 027, India

*Corresponding Author Email : basha.sheerin28@hotmail.com

Key words

Biodiesel,

Genomic DNA,

Lipid production,

Mould isolate,

Oleaginous moulds

\section{Publication Info}

Paper received : 18.03 .2017

Revised received : 27.03.2017

Re-revised received : 08.04.2017

Accepted: 02.05.2017

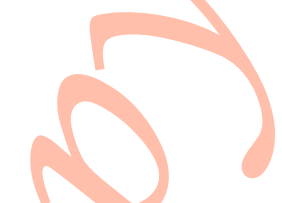

\section{Abstract}

Aim : The present study was carried out to isolate the moulds from garden soils of Lalbagh Botanical Garden and Cubbon Park Bangalore City, India and screen them for their oleaginicity.

Methodology : Several types of moulds were isolated randomly from garden soils and screened for their lipid production. Twenty five moulds were screened for their abilities to produce lipids. Potential lipid producers were identified by cultural method and confirmed by ITS region gene Sanger DNA sequencing. The fatty acid profile of two mould isolates was identified using GC-FID.

Results : Interestingly, two isolates such as GS7 and GS12 were found to be promising lipid producers among twenty five screened moulds, and maximum lipid contents found in GS7 and GS12 were 22 and $24.3 \%$, respectively. The mould isolates were identified as Penicillium citrinum (GS7) and Trichoderma asperellum (GS12) using colony characteristics and Sanger Sequencing. Consensus gene sequences were submitted to NCBI genbank and Accession numbers (KX865284 and KY623504) were obtained. The fatty acid profile of Pencillium citrinum showed $56.85 \%$ of saturated fatty acid (SFA), $32.20 \%$ of monounsaturated fatty acids (MUFA) and $10.95 \%$ polyunsaturated fatty acids (PUFA), while Trichoderma asperellum showed $47.73 \%$ ofsaturated fatty acid (SFA), $25.12 \%$ of monounsaturated fatty acids (MUFA) and $27.09 \%$ polyunsaturated fatty acids (PUFA), respectively.

Interpretation : GS7 (Penicillium citrinum) and GS12 (Trichoderma asperellum) described in the study were identified as promising lipid producers. This study would help in better selection of moulds for producing lipids which are suitable for biodiesel production.

Isolation of moulds from garden soils to assess oleaginicity

Screening of isolate for lipid production

Detection of potential lipid producers (GS7 and GS12) using Cultural and ITS gene Sanger Sequencing

\section{Assessment of lipid yield}

Identification of fatty acid profile in Penicillium citrinum (GS7) and Trichoderma asperellum (GS12) 


\section{Introduction}

Microorganisms have been receiving increased attention as source of novel lipids. Those that accumulate $20 \%$ and above are termed as oleaginous and their oils single cell oils (SCOs), unicellular oils or microbial oils (Akpinar-Bayizit, 2014). Microorganisms being ubiquitous have been recognized as potential sources of oils and fats. Oils and fats are both classed as lipids. Though bacteria, algae and yeasts are oleaginous they have some demerits and therefore, recent interest has centered upon moulds. Oleaginous moulds are single cell oil (SCO) producers that are capable of accumulating intracellular lipids under certain culture conditions. These moulds are an attractive source of lipids and show a greater diversity of fatty acids and higher proportion of polyunsaturated fatty acids (PUFA). The naturally isolated organisms are much variable in their characteristics. Screening of organisms for desired characteristics using selective medium is being adopted by various researchers (El-haj et al., 2015). Lipid accumulation in oleaginous moulds has been demonstrated to occur when a nutrient in the medium (e.g. the nitrogen or the phosphorous source) becomes limited and the carbon source is present in excess. The main focus of this study is on oleaginous moulds, as they can be easily grown in surface culture under static condition with cheap carbon sources, their life cycle is short and are not affected by space, light and climate, thus having several advantages comparatively to that of plants and algae (Pant et al., 2009; Yousuf et al., 2010; Khot et al., 2012). Molecular techniques exhibit high sensitivity and specificity for identifying microorganisms and can be used for classifying microbial strains at diverse hierarchical taxonomic levels (Sette et al., 2006). In view of the above, in the present study moulds were isolated from garden soils and screened for their oleaginicity and identified by classical and molecular methods.

\section{Materials and Methods}

Sample collection and isolation : Twenty five soil samples were collected from $5-15 \mathrm{~cm}$ below the surface of different garden soils of Lalbagh Botanical Garden and Cubbon Park, Bangalore city, in sterile plastic containers under aseptic conditions and stored at $4^{\circ} \mathrm{C}$ until further use. About $1 \mathrm{~g}$ of each soil sample was individually suspended in $1 \mathrm{ml}$ sterile distilled water, serially diluted to 10 fold and plated on Potato dextrose agar plates with pH 5.6. To suppress the bacterial growth, streptomycin (1 mg per $100 \mathrm{ml}$ ) was added to the medium. The plates were incubated at $28^{\circ} \mathrm{C}$ for 7 days in an incubator. Several mould colonies were obtained from different plates and were purified by picking small sample of hyphal spores, from each plate and transferred repeatedly to a new agar plate until pure cultures were confirmed. The pure cultures of moulds were maintained at $4^{\circ} \mathrm{C}$ by sub culturing at regular intervals.

Screening for oleaginous moulds: The spore suspension were prepared from well sporulated PDA slant cultures using $10 \mathrm{ml}$ of sterile distilled water with a drop of Tween 80 and the spores were counted using haemocytometer then were used as standard inocula $\left(1 \times 10^{6-1} 10^{8}\right.$ spores $\mathrm{ml}^{-1}$ medium) unless otherwise stated. One $\mathrm{ml}$ of inoculum was used to inoculate $50 \mathrm{ml}$ of sterile CzapekDox liquid medium in $250 \mathrm{ml}$ conical flasks.

The CzapekDox liquid medium consisted of $\mathrm{N}_{\mathrm{a}} \mathrm{H}_{2} \mathrm{PO}_{4} \cdot 2 \mathrm{H}_{2} \mathrm{O} ; \mathrm{K}_{2} \mathrm{SO}_{4} ; \mathrm{M}_{9} \mathrm{SO}_{4} \cdot 7 \mathrm{H}_{2} \mathrm{O} ; \mathrm{ZnSO}_{4} \cdot 7 \mathrm{H}_{2} \mathrm{O} ; \mathrm{FeCl}_{3} \cdot 6 \mathrm{H}_{2} \mathrm{O}$; $\mathrm{NH}_{4} \mathrm{NO}_{3}$ and Glucose with initial pH 6.8. Fifty ml of sterile medium was dispensed in $250 \mathrm{ml}$ conical flask inoculated with one $\mathrm{ml}$ of seed culture $\left(1 \times 10^{6}-10^{8}\right.$ spores $\left.\mathrm{ml}^{-1}\right)$ and then incubated at $28^{\circ} \mathrm{C}$ under static condition for 8 days.

Biomass dry weight determination : After 8 days of incubation, the culture flasks were harvested by filtration using pre-weighed filter (Whatman No.1) and the mycelia mats were rinsed three times thoroughly with sterile distilled water to remove extraneous materials. The biomass was dried and the weight of dried biomass was calculated.

Residual glucose estimation: The residual glucose in the culture filtrate was estimated by using dinitrosalicylic acid method according to Miller (1959).

Lipid extraction : The dried biomasses were finely ground to obtain the homogenous product, $2-5 \mathrm{~g}$ of dry powder was then wrapped by a single thickness filter paper to extract in a Soxhlet extraction apparatus with light petroleum ether $\left(40-60^{\circ} \mathrm{C}\right)$ as solvent for $10 \mathrm{hrs}$. The extracted lipid was dried at $60^{\circ} \mathrm{C}$ for 30 min, cooled and weighed.

Classical and molecular identification of most promising oleaginous mould isolates : Morphological characteristics (color, texture and diameter of the colonies) were studied by observing the growth on potato dextrose agar medium and microscopic characteristics were performed by staining with Lacto-phenol cotton blue to identify the mould isolates. The molecular identification of two promising oleaginous mould isolates GS7 and GS12 were indentified as Penicillium citrinum and Trichoderma asperellum, respectively.

Preparation of genomic DNA : Genomic DNA was extracted using Macherey-Nagel Nucleospin food kit. Genomic DNA concentration was measured using Thermo Scientific Nano Drop 8000 . and the average concentration for every sample obtained was about $40-50 \mathrm{ng} / \mu \mathrm{l}$.

Conventional PCR : To a MicroAmp® 96-well reaction plate $(0.2$ $\mathrm{ml}), 3 \mu \mathrm{l}$ buffer, $2 \mu \mathrm{l}$ DNTPS, $0.3 \mu \mathrm{l}$ Taq DNA polymerase (NEB, USA), $2 \mu \mathrm{l} 5 \mathrm{M}$ Betain, $2 \mu \mathrm{l}$ template, $2 \mu \mathrm{l}$ of 20 picomole primer forward, $2 \mu$ primer reverse and $6.7 \mu \mathrm{HPLC}$ water was added and then sealed accordingly with the applicator. The $\pm 600 \mathrm{bp}$ product of ITS region gene was amplified by using primer set ITS1-5'CTTGGTCATTTAGAGGAAGTAA3' and ITS45'TCCTCCGCTTATTGATATGC3' (Eurofins Genomics India Pvt. Ltd.). Amplification was carried out in Applied BiosystemsVeriti 96 well Thermal cycler system. Amplification by Conventional PCR process was started with initial denaturation step at $94^{\circ} \mathrm{C}$ for 3 
min). Each cycle consisted of three steps (denaturation, annealing, and extension). Each PCR reaction consisted of 40 cycles of amplification (initial 10 cycles was denaturation at $94^{\circ} \mathrm{C}$ for $1 \mathrm{~min}$, annealing at $50^{\circ} \mathrm{C}$ for $1 \mathrm{~min}$ and DNA chain extension at $72^{\circ} \mathrm{C}$ for $1 \mathrm{~min}$, last $30 \mathrm{cycles}$ was denatured at $94^{\circ} \mathrm{C}$ for $30 \mathrm{sec}$, annealing at $55^{\circ} \mathrm{C}$ for $10 \mathrm{sec}$ and DNA chain extension at $72^{\circ} \mathrm{C}$ for $30 \mathrm{sec}$ ). A final extension cycle was performed at $72^{\circ} \mathrm{C}$ for 5 min (Applied BiosystemsVeriti Thermal Cycler).

PCR products were detected by using Agarose gel electrophoresis. Electrophoresis was performed with $2 \%$ Agarose gel (Himedia) prestained with $0.5 \mu \mathrm{l}$ per $100 \mathrm{ml}$ of ethidium bromide $\left(10 \mathrm{mg} \mathrm{ml}^{-1}\right)$. Gels were run at $80 \mathrm{~V}$ using $1 \mathrm{X}$ TAE buffer and then photographed under UV illumination by using a Gel documentation system.

Sanger sequening : Amplified amplicons were purified using QIAquick PCR Purification kit (QIAGEN, Malaysia). The amplicons were sequenced automatically in both directions using BDT v3.1 chemistry, POP7 Polymer on 3730XL Genetic Analyzer. The thermal program was made up of an initial predenaturation step at $95^{\circ} \mathrm{C}$ for $2 \mathrm{~min}$; followed by 25 cycles consisting of a denaturation step at $95^{\circ} \mathrm{C}$ for 10 seconds, annealing step at $50^{\circ} \mathrm{C}$ for 10 seconds and an extension step at $60^{\circ} \mathrm{C}$ for $4 \mathrm{~min}$. Consensus sequences were generated from forward and reverse sequence data using aligner software.

Fatty acid composition and FAME analysis by GC-FID : The fatty acid profile of lipid sample was determined by converting fatty acids in lipid to fatty acid methyl esters (FAME). Lipid was transesterified (obtained after extraction) with $5 \mathrm{ml}$ of methylated mixture of methanol:sulfuricacid:toluene (2:1:1) for $8 \mathrm{hrs}$ in a water bath at $50^{\circ} \mathrm{C}$. Then FAME was recovered with $3 \mathrm{ml}$ of diethyl ether by vortex and the upper phase was passed through sodium sulphate anhydrous to eliminate the water. The sample was filtered in $0.2 \mu \mathrm{m}$ nylon filter and recovered. Fatty acid profile was analyzed by using gas chromatography (Agilent $6890 \mathrm{~N}$ ) with flame ionization detector (GC-FID). The column used was DB WAX (30 m x $0.25 \mathrm{~mm}$ ID). The chromatographic condition was as follows. The initial temperature of column was $50^{\circ} \mathrm{C}$, held for 2 min, then $10^{\circ} \mathrm{C} \mathrm{min}{ }^{-1}$ ramp to $230^{\circ} \mathrm{C}$ and held for $15 \mathrm{~min}$. The carrier gas was hydrogen at a flow rate of $2 \mathrm{ml} \mathrm{min}^{-1}$. Fatty acid identification was made by comparing with the relative retention time of FAME peaks from sample with standards. The results were recorded and processed using software Chemstation and expressed in relative $\%$ of each fatty acid.

\section{Results and Discussion}

Accession numbers for 2 isolates Penicillium citrinum (KX865284) and Trichoderma asperellum (KY623504), based on 100\% Sanger Sequence Similarity, was successfully obtained from NCBI Genbank.

The results of screening tests of the moulds for lipid accumulation ability is presented in Table 1 . Out of 25 mould isolates screened, only two strains were found to be oleaginous that produced and accumulated more than $20 \%$ lipid of their dry weight. GS12 Trichoderma asperellum showed highest (24.3\%) ability to accumulate lipids followed by GS7 Penicillium citrinum ( $22 \%$ of their dry weight). While other mould isolates were able to accumulate lipid less than the standard expected and were considered as non-oleaginous moulds.

In general, those microorganisms which utilized high sugar showed good growth and high lipid accumulation. All microorganisms cannot be considered as source of oils and fats. Organisms which accumulate $20 \%$ or more of their biomass as lipid have been termed as Oleaginous (Akpinar-Bayizit, 2014). Nitrogen limitation is the most efficient condition for inducing lipogenesis. During growth phase, nitrogen is necessary for synthesis of proteins and nucleic acids, while carbon flux is distributed among energetic and anabolic processes yielding carbohydrates, lipids, nucleic acids and proteins.

Table 1: Screening of different moulds for their oleaginicity

\begin{tabular}{|c|c|c|c|}
\hline $\begin{array}{l}\text { Mould } \\
\text { isolates }\end{array}$ & $\begin{array}{l}\text { Biomass dry } \\
\text { weight }\left(\mathrm{gl}^{-1}\right)\end{array}$ & $\begin{array}{l}\text { Total lipids } \\
\text { dry weight } \\
\left(\mathrm{gl}^{1}\right)\end{array}$ & $\begin{array}{l}\text { Lipid percentage } \\
\text { to biomass dry } \\
\text { weight (\%) }\end{array}$ \\
\hline GS1 & 5.4 & 1.03 & 19 \\
\hline GS2 & 5.1 & 0.56 & 10.9 \\
\hline GS3 & 6.2 & 0.51 & 8.2 \\
\hline GS4 & 5.6 & 0.5 & 8.9 \\
\hline GS5 & 6.2 & 0.86 & 13.8 \\
\hline GS6 & 3.74 & 0.46 & 12.2 \\
\hline $\begin{array}{l}\text { GS7 } \\
\text { (Penicillium } \\
\text { citrinum) } \\
\end{array}$ & 4.3 & 0.95 & 22 \\
\hline GS8 & 3.56 & 0.36 & 10.1 \\
\hline GS9 & 4.68 & 0.49 & 10.4 \\
\hline GS10 & 5.6 & 0.72 & 12.8 \\
\hline GS11 & 1.17 & 0.1 & 8.5 \\
\hline $\begin{array}{l}\text { GS12 } \\
\text { (Trichoderma } \\
\text { asperellum) }\end{array}$ & 3.16 & 0.77 & 24.3 \\
\hline GS13 & 3.8 & 0.74 & 19.4 \\
\hline GS14 & 3.6 & 0.25 & 6.9 \\
\hline GS15 & 5.6 & 0.31 & 5.5 \\
\hline GS16 & 4.46 & 0.33 & 7.3 \\
\hline GS17 & 5.2 & 0.8 & 15.3 \\
\hline GS18 & 5.02 & 0.19 & 3.7 \\
\hline GS19 & 5.26 & 0.45 & 8.5 \\
\hline GS20 & 4.14 & 0.22 & 5.3 \\
\hline GS21 & 5.5 & 0.89 & 16.1 \\
\hline GS22 & 5.3 & 0.72 & 13.5 \\
\hline GS23 & 4.1 & 0.64 & 15.6 \\
\hline GS24 & 4.68 & 0.49 & 10.4 \\
\hline GS25 & 4.1 & 0.58 & 14.1 \\
\hline
\end{tabular}


Table 2 : Fatty acid methyl ester composition in moulds

\begin{tabular}{|c|c|c|c|}
\hline \multicolumn{2}{|c|}{ Methyl esters of fatty acid } & $\begin{array}{l}\text { Pencillium } \\
\text { citrinum (\%) }\end{array}$ & $\begin{array}{l}\text { Trichoderma } \\
\text { asperellum (\%) }\end{array}$ \\
\hline \multicolumn{4}{|c|}{$\begin{array}{l}\text { Total saturated fatty } \\
\text { acids (SFA) }\end{array}$} \\
\hline Caproic acid & $(\mathrm{C} 6: 0)$ & 0.42 & Nil \\
\hline Caproic acid & $(\mathrm{C} 6: 0)$ & 0.42 & Nil \\
\hline Caprillic acid & (C8:0) & 0.25 & Nil \\
\hline Capric acid & $(\mathrm{C} 10: 0)$ & Nil & Nil \\
\hline Lauric acid & (C12:0) & Nil & 0.26 \\
\hline Myristic acid & (C14:0) & 0.75 & 0.62 \\
\hline Palmitic acid & (C16:0) & 34.99 & 36.71 \\
\hline Strearic acid & $(\mathrm{C} 18: 0)$ & 20.44 & 10.14 \\
\hline \multicolumn{4}{|c|}{$\begin{array}{l}\text { Total manounsaturated } \\
\text { fatty acids ( MUFA) }\end{array}$} \\
\hline Oleic acid & (C18:1 n9) & 32.2 & 24.47 \\
\hline Erucic acid & (C22:1w9) & Nil & 0.72 \\
\hline \multicolumn{4}{|c|}{$\begin{array}{l}\text { Total polyunsaturated fatty } \\
\text { acids (PUFA) }\end{array}$} \\
\hline Linoleic acid & $(\mathrm{C} 18: 2 n 6 c)$ & Nil & 0.42 \\
\hline Linolenic acid & $(\mathrm{C} 18: 3 \mathrm{n} 3)$ & 9.92 & 25.41 \\
\hline Arachidonic acid & $(\mathrm{C} 20: 1 \mathrm{c})$ & 1.03 & 0.63 \\
\hline Behenic acid & $(\mathrm{C} 22: 0)$ & Nil & Nil \\
\hline Lignoceric acid & $(\mathrm{C} 24: 0)$ & Nil & 0.63 \\
\hline Recenoleic acid & (C18:0) & Nil & Nil \\
\hline SFA & & 56.85 & 47.73 \\
\hline MUFA & & 32.2 & 25.12 \\
\hline PUFA & & 10.95 & 27.09 \\
\hline
\end{tabular}

Several reseachers have reported that when nitrogen gets limited, the growth rate slows down and synthesis of proteins and nucleic acids tends to cease, but excess of carbon continues to be metabolized to lipid (Wynn et al., 2001; Beopoulos et al., 2009). In oleaginous species, the excess carbon is channeled towards lipid synthesis, leading to accumulation of triacylglycerol within intracellular lipid bodies (Ratledge and Wynn, 2002; Akpinar-Bayizit, 2014). Triacylglycerols consist of three fatty acids linked to three carbon with varying properties from fats to oils (Christie, 2003). However, lipid accumulation by microorganisms varies depending on strain specificity of the organisms and various cultural conditions.

Oleaginicity is related to lipid producing ability of moulds. The lipids of moulds (filamentous fungi) show diversity in fatty acids. The lipids of oleaginous microorganisms contain good fraction of saturated fatty acids than unsaturated fatty acids (Papanikolaou et al., 2004; Wahlen et al., 2011; Venkata Mohan et al., 2011).Saturated fatty acids do not have double bonds and unsaturated fatty acids with one double bond are known as monounsaturated fatty acids (MUFA) and with more double bonds are known as polyunsaturated fatty acids (PUFA) (Gurr et al., 2008). Thus, the profile of lipids from Penicillium citrinum and Trichoderma asperellum was studied to find the type of fatty acids present.
The FAME analysis of lipids produced by both Penicillium citrinum and Trichoderma asperellum is presented in Table 2. Pencillium citrinum showed $56.85 \%$ SFA, $32.20 \%$ MUFA, $10.95 \%$ PUFA, while Trichoderma asperellum showed $47.73 \%$ SFA, $25.12 \%$ MUFA and $27.09 \%$ PUFA. GC-FID study revealed that the fraction of saturated fatty acids consisted of $34.99 \%$ palmitic acid (C16:0), 20.44\% strearic acid (C18:0) and MUFA, 32.20\% oleic acid (C18:1 n9) and 9.92\% linolenic acid (C18:3n3) PUFA in Pencillium citrinum. In Trichoderma asperellum, 36.71\% palmitic acid (C16:0), 10.14\% strearic acid (C18:0) SFA, $24.47 \%$ oleic acid (C18:1n9) MUFA and $25.41 \%$ linolenic acid (C18:3n3) PUFA was noted. A small percentage of fatty acids mainly C6, C8, C14 (SFA), C20 (PUFA) in Pencillium citrinum and C12 and C14 (SFA), C22 (MUFA), PUFA C18:2n6c and C20:1c in case of Trichoderma asperellum were found in lipid samples. The result of the present study is in agreement with Xie et al. (2013) who reported that lipid extract of Fusarium sp. ML-GEN.1 mainly contained oleic acid $(41.66 \%)$, palmitic acid $(23.26 \%)$ and linoleic acid $(19.18 \%)$. Similarly, Ziino et al. (1999) found that stearic acid and hexadecanoic acid was the most abundant fatty acid isolated from Geotrichum. In addition, Thanaa et al. (2014) showed that the fatty acids palmitic, linoleic and linolenic acid were predominant in the lipid sample of Trichoderma viridie NRC 314.

Palmitic (C16), stearic (C18), oleic (C18) and linolenic (C18) acid in lipid samples tend to give more favorable properties of biodiesel and hence, can be useful for biodiesel production. However, for optimized biodiesel both long-chain saturated and polyunsaturated fatty acids should be present (Wynn et al., 2001; Gadallah et al., 2014).

In conclusion, several fungal isolates were screened for their lipid production ability. Two of them GS7 (Penicillium citrinum) and GS12 (Trichoderma asperellum) were identified as promising lipid producers with maximum lipid yield and favorable for biodiesel production.

\section{Acknowledgment}

We would like to thank Mr. Ananda A.P. for GC-FID analysis and reviewing the manuscript.

\section{References}

Akpinar-Bayizit, A. : Fungal lipids: The biochemistry of lipid accumulation. Int. J. Chem. Eng. Appl., 5, 409-414 (2014).

Beopoulos, A., T. Chardot and J.M. Nicaud: Yarrowia lipolytica: Amodel and $a$ tool to understand the mechanisms implicated in lipid accumulation. Biochimie., 91, 692-696 (2009 a).

Christie, W.W. : Lipid Analysis. ${ }^{\text {rd }}$ Edn.,The Oily Press, Ayr, Scotland (2003).

El-haj, M., Z. Olama and H. Holail: Biodiversity of oleaginous microorganisms in the Lebanese environment. Int. J. Curr. Microbiol. Appl. Sci., 4, 950-961 (2015).

Gadallah, A.E. and D. Abd-El-Haleem: Promising oleaginous filamentous fungi as biodiesel stocks: Screening and Identification, Europ. J. Exper. Biol., 4, 576-582 (2014).

Gurr, M.I., J.L. Harwood and K.N. Frayn : Lipid Biochemistry : An 
Introduction. $5^{\text {th }}$ Edn., JohnWiley \& Sons, pp.13-92 (2008).

Khot, M., S.Kamat, S. Zinjarde, A. Pant, B. Chopade and A. Ravikumar: Single cell oil of oleaginous fungi from the tropical mangrove wetlands as a potential feedstock for biodiesel. Microbial Cell Factories.,11,71(2012).

Miller, G.: Use of dinitrosalicylic acid reagent for determination of reducing sugar. Analytical Chemistry, 31, 426-428 (1959).

Pant, D. and A. Adholeya : Nitrogen removal from biomethanenated spent wash using hydroponic treatment followed by fungal decolorization. Env. Eng. Sci., 26, 559-565 (2009).

Papanikolaou, S., M. Komaitis and G. Aggelis : Single cell oil (SCO) production by Mortierella isabellina grown on high-sugar content media. Bioresour. Technol., 95, 287-291 (2004).

Ratledge, C. and J. Wynn : The biochemistry and biotechnology of lipid accumulation in oleaginous microorganisms. Adv. Appl. Microbiol., 51, 1-51 (2002).

Sette, L.D., M.R.Z. Passarini, C. Delarmelina, F. Salati and M.C.T. Duarte : Molecular characterization and antimicrobial activity of endophytic fungi from coffee plants. World J. Microbio. Biotechnol., 22,11851195 (2006).

Thanaa, H. Ali and Dina H. El-Ghonemy : Optimization of culture conditions for the highest lipid production from some oleaginous fungi for biodiesel preparation. Asian J. Appl. Sci., 2, 600-609 (2014).
Venkata Mohan, S., M. Prathima Devi, G. Mohanakrishna, N. Amarnath, M. Lenin Babu and P. N. Sarma : Potential of mixed microalgae to harness biodiesel from ecological water bodies with simultaneous treatment. Bioresour. Technol., 102, 1109-1117 (2011).

Wahlen, B.D., R.M. Willis and L.C Seefeldt : Biodiesel production by simultaneous extraction and conversion of total lipids from microalgae, cyanobacteria and wild mixed - cultures. Bioresour. Technol., 102, 2724-2730 (2011).

Wynn, J.P., A.A. Hamid, Y. Li and C. Ratledge: Biochemical events leading to the diversion of carbon into storage lipids in the oleaginous fungi Mucor circinelloides and Mortierella alpine. Microbiology, 147, 2857-2864 (2001).

Xie, J., L. Song, X. Li, Q. Wu, C. Wang, H. Xu, Y. Cao and D. Qiao: Isolation and identification of oleaginous endophytic fungi. African J. Microbiol. Res., 7, 2014-2019 (2013).

Yousuf, A., F. Sannino, V. Addorisio and D. Pirozzi : Microbial conversion of olive oil mill waste waters into lipids suitable for biodiesel production. J.Agri. Food Chem., 58, 8630-8635 (2010).

Ziino, M., R. Lo Curt, F. Salvo, D. Signorino, B. Chiofalo and D.Giuffrida: Lipid composition of Geotrichum candidum single cell protein grown in continuous submerged culture. Bioresource Technol., 67, 7-11 (1999). 